This is an electronic reprint of the original article. This reprint may differ from the original in pagination and typographic detail.

Author(s): Kontinen, Tanja; Ojala, Arto

Title: International opportunity recognition among small and medium-sized family firms

Year: $\quad 2011$

Version:

Please cite the original version:

Kontinen, T., \& Ojala, A. (2011). International opportunity recognition among small and medium-sized family firms. Journal of Small Business Management, 49(3), 490514. https://doi.org/10.1111/j.1540-627X.2011.00326.x

All material supplied via JYX is protected by copyright and other intellectual property rights, and duplication or sale of all or part of any of the repository collections is not permitted, except that material may be duplicated by you for your research use or educational purposes in electronic or print form. You must obtain permission for any other use. Electronic or print copies may not be offered, whether for sale or otherwise to anyone who is not an authorised user. 


\title{
International Opportunity Recognition among Small and Medium-Sized Family Firms*
}

\author{
by Tanja Kontinen and Arto Ojala
}

Current research in the field of entrepreneurship emphasizes the importance of opportunity recognition as a key element in the entrepreneurial process. It has been recognized that network ties, activeness and alertness, and prior knowledge are related to how entrepreneurs recognize new opportunities. However, it is unclear how important these factors are when a firm explores opportunities for entry into a foreign market. In this exploratory case study, covering the international opportunity recognition of eight family-owned small and medium-sized enterprises (SMEs), we found that the firms in question mainly recognized international opportunities by establishing new formal ties rather than using existing informal or family ties. The findings also indicated that due to the small size and the flexibility of the management team in family SMEs, these firms were able to react quickly to new international opportunities. However, there was no direct relationship between the prior knowledge of the firms and their international opportunity recognition. In addition, we found that trade exhibitions formed the primary context for the international opportunity recognition of the SMEs in this study. These findings motivate a set of five propositions that may lead to further studies on this topic.

*The authors would like to thank three anonymous reviewers for their valuable comments and suggestions. In addition, they would like to thank Juha Kansikas and Pasi Tyrväinen for their research assistance. The research has been generously funded by Marcus Wallenberg Foundation.

Tanja Kontinen is working as senior assistant of entrepreneurship in Jyväskylä University School of Business and Economics. Her research interests include entrepreneurial internationalization, family business, networks and social capital. Tanja Kontinen has published in International Business Review, Journal of Small Business and Enterprise Development, and Family Business Strategy among others.

Arto Ojala (Ph.D., Econ.) is working as senior researcher in the Department of computer science and information systems at the University of Jyväskylä. His research interests include international entrepreneurship, software business, and network relationships in a firm internationalization. His articles have been published in Journal of International Marketing, International Business Review, and European Management Journal among others.

Address correspondence to: Tanja Kontinen, $\cdots$, Jyväskylä University School of Business and Economics, PO Box 35, • 40014, Finland. Tel: +358142603363; Fax: +358142603331; E-mail: tanja.kontinen@jyu.fi. 


\section{Introduction}

The recognition of business opportunities is a key aspect of the entrepreneurial process (Shane and Venkataraman 2000). Accordingly, recent years have witnessed growing interest in opportunity recognition among researchers on entrepreneurship. Since opportunities exist both in domestic and international markets (Zahra, Korri, and Yu 2005), scholars in the field of international entrepreneurship have called for more research on opportunity recognition in international settings (Dimitratos and Jones 2005; Ellis 2008; Zahra, Korri, and Yu 2005), suggesting that such research is fundamental for the development of the field (Oviatt and McDougall 2005). However, there has not so far been much empirical research on opportunity recognition within international entrepreneurship (Zahra, Korri, and Yu 2005).

Studies on international entrepreneurship have commonly focused on rapidly internationalizing firms such as born

2 globals or international new ventures (Dimitratos and Jones 2005) in knowledge-intensive fields (Coviello and Jones 2004). However, international entrepreneurship can be defined on a broader basis as "... discovery, enactment, evaluation, and exploitation of opportunities-across national bordersto create future goods and services" (Oviatt and McDougall 2005, p. 540). This definition makes no reference to the actual speed of internationalization or to the industry. Scholars have therefore called for research that would go beyond early internationalizing firms (Young, Dimitratos, and Dana 2003) and include a wider variety of enterprises (Coviello and Jones 2004; Dimitratos and Jones 2005).

The aim of this paper is to respond to the calls referred to above, generating two contributions to the field of international entrepreneurship. First, we shall examine the international opportunity recognition of small and medium-sized enterprises (SMEs); in other words, we shall look at how such firms recognize the opportunities available to enter a foreign market. Second, we shall take family-owned SMEs as the target group of our empirical study. Family-owned SMEs, with few exceptions, internationalize their activities in a later phase of their life cycle, and their internationalization process is slower than that of firms with other types of ownership structure (Graves and Thomas 2008). These two research gaps-referred to by a number of scholars (Dimitratos and Jones 2005; Ellis 2008; Young, Dimitratos, and Dana 2003; Zahra, Korri, and Yu 2005)—must be addressed if we are to gain a fuller understanding of the field of international entrepreneurship.

In previous studies, opportunity recognition has mainly been considered from the perspectives of (1) prior knowledge (Kirzner 1979; Shane 2000; Venkataraman 1997), (2) social ties (Ellis 2008; Ozgen and Baron 2007), and (3) entrepreneurial activeness and alertness (Kirzner 1997; Shane 2000). The present paper combines these three aspects, assessing their role in the foreign market entry of family SMEs. This will enable us to gain a more holistic understanding of the issue in the context of family SMEs-firms that are often cautious and that tend to have limited financial resources (Gallo and Pont 1996). It will also help us in discussing the actual primary context of their opportunity recognition.

In order to address this issue, the following research questions were set in relation to the firms we studied: (1) what kinds of network ties were involved in opportunity recognition? (2) What was the level of active search and alertness among the entrepreneurs, in terms of recognizing the foreign market entry opportunity? (3) What was the nature/ extent of the prior knowledge of the entrepreneur, when the international opportunity was recognized? 
This paper is organized as follows: we shall begin with the theoretical background, briefly discussing the internationalization of family firms, and then introduce some central concepts in opportunity recognition. Thereafter, we shall review the literature on international opportunity before proceeding to methodological considerations. The findings of the study will then be presented, followed by discussion. To conclude, the contributions and limitations of the study will be discussed.

\section{Internationalization of Family SMEs}

Internationalization of family SMEs has been argued to be different from internationalization of SMEs with different kinds of ownership structures (Fernandez and Nieto 2005; Graves and Thomas 2006; Kontinen and Ojala 2010). This may be because of their limited growth objectives (Donckels and Fröhlich 1991), a desire to avoid risks (Claver, Rienda, and Quer 2008), an unwillingness to borrow from external sources to facilitate international expansion (Graves and Thomas 2006), or to limited financial capital (Gallo and Pont 1996). An important facilitating factor in the internationalization of family SMEs has been found to be the ability to make quick decisions (Gallo and Pont 1996; Tsang 2001). However, family SMEs do not monitor the international marketplace regularly nor do they integrate global developments into their domestic decisions (Okoroafo 1999).

Family SMEs are less likely to form networks with other businesses than nonfamily SMEs (Graves and Thomas 2004). It has been argued that this is due to the strong internal ties of family firms based on trustful relationships between family members (Gomez-Mejia, Makri, and Kintana 2010; Salvato and Melin 2008). Such ties can also be called "family capital" (Arregle et al. 2007; Salvato and Melin 2008). Family capital naturally affects all decisions on the strategy, operations, and administrative struc ture of the family firm (Chrisman, Chua, and Steier 2005). Yet external ties, too, are important for family firms (Arregle et al. 2007), especially in the context of their internationalization, since they help in obtaining information from outside the firm.

\section{Opportunity Recognition}

As acknowledged in several studies (Baron 2006; Shane 2000; Shane and Venkataraman 2000), opportunities have a critical role in the entrepreneurial process. However, although opportunities may exist, they can be exploited only if an entrepreneur recognizes the opportunity and understands its value for further business (Shane and Venkataraman 2000). Hence, the main point of interest in research on opportunity recognition has been why certain individuals discover opportunities that others do not (Kirzner 1979; Shane 2000; Shane and Venkataraman 2000; Venkataraman 1997). Of particular relevance, here are Austrian theories ${ }^{1}$ according to which the possession of idiosyncratic information allows people to see particular opportunities that others do not perceive. Nevertheless, it must be acknowledged that opportunity recognition is only the initial phase in a continuing process; it is distinct from the actual evaluation of the feasibility of the opportunities identified,

${ }^{1}$ In the view presented by neoclassical economists (for instance Khilström and Laffont 1979), there is an assumption of public knowledge indicating that all opportunities must be equally "obvious" to everyone. In psychological theories, by contrast, human attributes (such as the need for achievement, willingness to bear a risk, and self-efficacy) lead some people but not others to become entrepreneurs. The question is explored more fully in for instance Shane (2000) and Shane and Venkataraman (2000). 
or active efforts to develop them through new ventures (Ardichvili, Cardozo, and Ray 2003).

Information plays a central role in opportunity recognition (Ozgen and Baron 2007; Shane 2000; Shane and Venkataraman 2000). Information involving patterns of changing conditions-for instance, changes in technological, economic, political, social, or demographic circumstances-can be regarded as a source of opportunity recognition (Baron 2006). Thus, opportunities come into existence at a certain point because of a certain confluence. Nevertheless, on an individual level, cognitive structures defining the identification of opportunities are developed through the previous life experiences of the person in question. Different individuals have different abilities to "connect the dots" they have perceived (Baron 2006). Hence, opportunity recognition can be defined as "the cognitive process (or processes) through which individuals conclude that they have identified an opportunity" (Baron 2006, p. 107).

Opportunity recognition can be assessed from several perspectives. In this paper, which takes its starting point from earlier studies (Baron 2006; Ellis 2008; Ozgen and Baron 2007; Shane 2000; Singh 2000), the phenomenon is studied from the perspective of (1) network ties, (2) activeness and the alertness in searching for opportunities, and (3) prior knowledge. Each of these perspectives will be presented below more in detail. Finally, the phenomenon will be placed in an international context by means of a short overview of the studies concerning international opportunity recognition.

\section{Network Ties}

It has been suggested that an entrepreneur's contacts with other persons (Crick and Spence 2005; Ellis 2008; Ozgen and Baron 2007; Singh 2000) are important in opportunity recognition: the extent of an entrepreneur's socia network is positively related to opportunity recognition. Social ties serve as conduits for the spread of information concerning new opportunities (Burt 2004; Granovetter 1973), and the ability to recognize novel opportunities may be determined by the reach and abundance of one's ties with others. An interesting point in this regard is that information on opportunities tends to arrive via links from separate social clusters (Burt 2004).

Ozgen and Baron (2007) discovered that the greater the extent of social ties with mentors and informal industry networks, the more positive were the effects on opportunity recognition. However, social relationships with family members and close friends did not increase the ability to recognize new opportunities. It was surmised that this was due to the lower industry-specific knowledge and experience of family members and close friends. In addition to social ties, which commonly refer to nonformal relationships, entrepreneurs may have formal ties with other business partners or institutions (Coviello 2006; Johanson and Mattsson 1992; Ojala 2009); these, too, serve as an important source of knowledge related to new opportunities.

In addition to what have been described, professional forums (Ozgen and Baron 2007) and trade exhibitions (Ellis 2008; McAuley 1999; Meyer and Skak 2002; Reid 1984) have been found to be sources for information and social ties, creating the potential for entrepreneurial opportunity recognition. However, the role of exhibitions as a source of social ties is complex. According to Ellis (2000), in the context of exhibitions, the communication of opportunities cannot be uniquely attributed to a buyer, a seller, or a third party (such as a government agency). Hence, Ellis (2000) suggests that it is appropriate to treat exhibitions as a special kind of initiation scenario. The particular nature of exhibitions is highlighted in the studies of Reid (1984) and 
McAuley (1999), who found that participation in international exhibitions generated more information about international opportunities than any other information source. Trade exhibitions and similar forums where people share common interests are a context with a dense network: the proportion of potential network ties is high (Coviello 2006). Such a context facilitates access to important information, since persons in the network can easily share essential knowledge (compare Burt 2000).

\section{Activeness and Alertness in the Search for Opportunities}

The active role of entrepreneurs in the search for new information is important in opportunity recognition (Baron 2006; Hills and Schrader 1998). Hills and Schrader (1998) found that for entrepreneurs, an active search for opportunities through personal contacts was regarded as more beneficial than the identification of opportunities from public information sources such as magazines and newspapers. However, some studies suggest that entrepreneurs, in many cases, recognize valuable information by accident without actively searching for opportunities (Ardichvili, Cardozo, and Ray 2003; Kirzner 1997). Thus, Shane (2000) found that none of the case firms in his study actively sought out opportunities prior to their discovery. Instead, the opportunity was recognized accidentally when the entrepreneur heard about some product from a person involved in its development process. These considerations lead to the activity level in the search for opportunities being categorized as either active or passive (Ardichvili, Cardozo, and Ray 2003; Baron 2006).

In the passive search, where opportunities are recognized accidentally, researchers stress the role of alertness in opportunity recognition. In such a case, individuals are receptive to opportunities but do not engage in a systematic search for them (Ardichvili, Cardozo, and Ray
2003; Kirzner 1997). According to Kirzner (1997), a systematic search is likely to be for a piece of missing information, whereas a discovery includes the surprise that accompanies the recognition of opportunities that were readily available. Factors contributing to a high level of alertness are related to the cognitive capacities of individuals such as high intelligence and creativity (Shane 2000), or optimism (Krueger and Brazeal 1994). However, sometimes alertness does indeed occur in a case in which a firm conducts an active search leading to recognition of a totally unexpected solution; hence, alertness has a central role in opportunity recognition, whether or not an active search is involved (Hohenthal, Johanson, and Johanson 2003).

\section{Prior Knowledge}

Prior knowledge in association with high-level cognitive capabilities is important in identifying and pursuing an opportunity (Baron 2006; Shane 2000; Shane and Venkataraman 2000). The individual cognitive structures defining the identification of opportunities are developed through the previous life experiences of individuals. Venkataraman (1997) referred to this as a "knowledge corridor," which allows the individual to recognize certain opportunities but not others. Sarasvathy, Simon, and Lave (1998) also noted that different individuals discovered different opportunities, according to their particular way of gathering and processing information.

Three major dimensions of prior knowledge, namely knowledge of markets, knowledge of ways to serve the markets, and knowledge of customer problems, have been regarded as important for entrepreneurial discovery (Shane 2000). In addition, current jobs, work experience (Aldrich 1999), and technological knowledge (Park 2005) are considered to be the general sources in facilitating opportunity recognition. In an international setting, "the knowledge of 
opportunities or problems is assumed to initiate decisions" for foreign market entry (Johanson and Vahlne 1977, p. 27). Such internationalization knowledge can be divided into general knowledge and market-specific knowledge. General internationalization knowledge is objective and easily acquired, for example, through the media, whereas marketspecific knowledge consists of earlier experiences in a particular market (Johanson and Vahlne 1977). It has been found that experiences gained in foreign markets have a positive effect on opportunity recognition and on the speed of internationalization (Oviatt and McDougall 1995, 2005; Reuber and Fischer 1997).

\section{International Opportunity Recognition}

Opportunity recognition plays a central role in the internationalization of firms. In the international context, opportunities are recognized in foreign markets and exploited by using resources from diverse national locations (Dimitratos and Jones 2005; Ellis 2008; Oviatt and McDougall 2005; Zahra, Korri, and Yu 2005). Ellis (2008, pp. 3-4) defines international opportunity as "the chance to conduct exchange with new foreign partners." Exchanges can be conducted with customers, distributors, licensees, franchisees, contract manufacturers, joint venture partners, and so on (Ellis 2008). Zahra, Korri, and Yu (2005) describe international opportunity recognition as an iterative process whereby the entrepreneur revises his or her concept several times, on the basis of intuition, formal and informal feedback, and the results of errors. They also emphasize that entrepreneurs make their foreign market entry decisions by utilizing both rational and nonrational elements.

There is no doubt that opportunity recognition is related to success in international markets and to the speed of internationalization (Dimitratos and
Jones 2005; Hohenthal, Johanson, and Johanson 2003; Oviatt and McDougall 2005). Opportunities in foreign markets can be recognized by using competencies such as networks and previous experiences that are unique to entrepreneurs (McDougall, Shane, and Oviatt 1994). Ellis (2008) recognized four different means for recognizing opportunities in a foreign market, namely: (1) formal searches, (2) participation in international trade fairs or exhibitions, (3) social ties, and (4) responses to advertisements. Hence, not all opportunities arose from existing networks, although networks and social ties played an important role in international opportunity recognition. For instance, the foreign market selection might be grounded on the opportunityseeking behavior of entrepreneurs. As Ojala (2008) found, business opportunities (such as demand and a market potential for niche products) constituted the main reason for managers of Finnish software firms to decide to enter the Japanese market. Thus, awareness of opportunities in foreign markets can be an initiator for foreign market entry (Dimitratos and Jones 2005). On the other hand, limited domestic markets can also be a reason for entrepreneurs to search for opportunities in international markets. Crick and Spence (2005) found that most of the case firms in their study internationalized rapidly because of market opportunities overseas being greater than those in domestic markets. Hence, firms can expand their international operations through a combination of searches and accidental opportunity recognitions (Hohenthal, Johanson, and Johanson 2003).

\section{Methodology}

The study reported here utilized a qualitative approach. Such an approach is suitable when the aim is to describe research objects holistically and when the research concerns real-life situations. According to Creswell (1997, p. 15), 
qualitative research is "an inquiry process of understanding based on distinct methodological traditions of inquiry that explore a social or human problem. The researcher builds a complex, holistic picture, analyzes words, reports detailed views of informants, and conducts the study in a natural setting." Thus, we used a multiple case study methodology similar to the approaches introduced by Eisenhardt (1989) and Yin (1994). This enables an in-depth investigation and the explanation of cause-and-effect relationships. It also makes it possible to use replication logic, so that the researchers are able to identify the subtle similarities and differences within a collection of

6 cases (Brown and Eisenhard 1997; Eisenhardt 1989; Yin 1994). The case study method is relevant in a situation where the study covers a real-life environment in which an action such as opportunity recognition occurs (Yin 1994). In this connection, Shane (2000, p. 453) argues that the case study method allows the investigation of how opportunity recognition operates in a situation where "all of the relevant behaviors cannot be manipulated through experimental design." In addition, the approach is consistent with numerous recent studies concerning international entrepreneurship and opportunity recognition research (Coviello 2006; Coviello and Munro 1997; Crick and Spence 2005; Ojala 2008, 2009; Shane 2000).

The phenomenon of international opportunity recognition was studied in the context of SMEs for the principal reason that opportunity recognition is more transparent in such enterprises. Hence, we followed Yin (1994) in selecting cases in which the phenomenon studied was transparently observable. The dimension of family ownership also allows us to recognize how firms with limited resources recognize international opportunities. It should further be noted that the selection of the firms for investigation was based on an overall theoreti- cal perspective, as recommended in the study of Eisenhardt (1989), rather on a random sampling methodology.

These various considerations led us to collect data from eight selected Finnish family SMEs in the manufacturing sector. As can be seen in Table 1, the range of products in the case firms is fairly wide, but all of the firms manufacture material goods. We chose market entry to the French market as the context for international opportunity recognition. This allowed us to investigate opportunity recognition in a context that would be uniform for all the firms involved in the study (compare Shane 2000), bearing in mind that laws, regulations, and customs might vary in different markets (Shrader, Oviatt, and McDougall 2000). In addition, it seems that France is a somewhat difficult market for Finnish family SMEs to enter despite its market potential (Finpro 2008), and this would underline the importance of opportunity recognition in this context.

All the case firms had fewer than 250 employees at the time of entry to the French market. Thus, they fulfilled the criteria of the Finnish government and the EU for classification as SMEs (Organization for Economic Co-operation and Development 2003). As far as the definition of a family firm is concerned, it can be defined as one in which the family controls the largest block of shares or votes, has one or more of its members in key management positions, and has members of more than one generation actively involved within the business. This definition is based on the two criteria of ownership and management presented, for instance, by Graves and Thomas (2008), and on the factor of continuity (see for instance Zahra 2003). Table 1 summarizes the key information on the case firms. The firms were established between 1876 and 1988. The number of personnel varies from 18 to 249 employees, the average being 106 employees. 
JOBNAME: No Job Name PAGE: 8 SESS: 21 OUTPUT: Fri Apr 8 18:27:35 2011 SUM: 3F1BB5DF /v2503/blackwell/journals/jsbm_v49_i3/jsbm_326

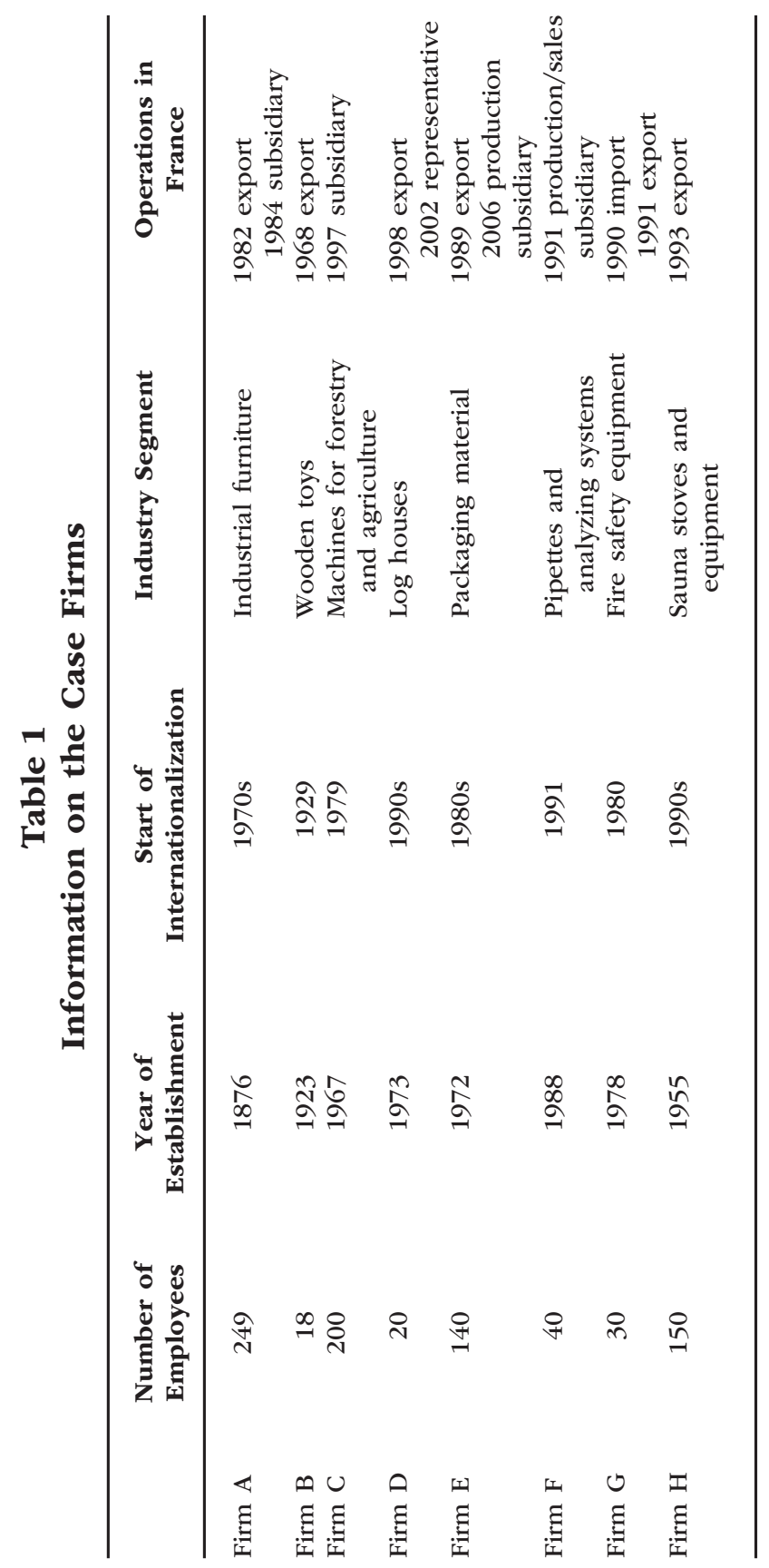


Multiple sources of information were used to gather data from each case firm. The main form of data collection was a semi-structured interview, guided by a list of topics. The interviews were conducted by one of the authors, a researcher who was fluent in English and French, and who had experience of living in French speaking countries (and hence cultural knowledge and understanding). The interviewer followed the guidelines set out by Huber and Power (1985) to minimize the risk of providing inaccurate or biased data. Altogether, 16 semistructured, open-ended interviews lasting 60-90 minutes were conducted with two respondents from each firm, in the firm's headquarters in Finland and/or its subsidiary/agency in France. The interviewees selected consisted of executives, managing directors, subsidiary managers, managers of international affairs, and those sales administrators who had the greatest in-depth knowledge of internationalization and operations in France. These professions correspond to the informants commonly utilized in the field of international entrepreneurship (see Coviello and Jones 2004). By selecting the most knowledgeable persons and by using two informants from each firm, we aimed to get the most relevant knowledge and to counteract the biases of individual opinions (Huber and Power 1985). Having two interviews from each case firm also made it possible to ask more detailed questions of the second interviewee, following on from the first interview. Working in this way improved the validity of the data collected.

In the interview process, semistructured, open-ended interviews were conducted. The approach made it possible to ask "main" questions and then to pose further, more detailed questions (Yin 1994). The interviewees were first

8 asked to describe their business in general, thereafter their operations related to internationalization as a whole, and from that the business connected to internationalization in France in particular. Based on general information on the entry to the French market, more detailed questions were then asked about the following issues: (1) the firm's activity in pursuit of entry to France, (2) important events, persons, firms, or organizations that influenced the entry to France, and (3) the firm's knowledge and experiences concerning the French market. All these questions were developed according to the guidelines issued by Yin (1994), with the aim of making the questions as nonleading as possible. This encouraged the interviewees to give authentic answers to the interview questions. Because the interviews focused on the entrepreneurs' past experiences, we followed the guidelines for retrospective studies issued by Miller, Cardinal, and Glick (1997) and by Huber and Power (1985).

All the interviews were digitally recorded and transcribed verbatim. A second listening was conducted to ensure correspondence between the recorded and the transcribed data. The complete case reports were sent back to the interviewees, and any inaccuracies they noticed were corrected. In addition, e-mail communication was used to collect further information and to clarify any inconsistent issues. To improve the validity of the study, we collected and analyzed many types of secondary information (such as websites and annual reports). By comparing the interview data with other documents from the case firms, we carried out triangulation on the information (Bonoma 1985; Miles and Huberman 1994). This also provided a more complete picture of the case firms under study (Bonoma 1985).

The unit of analysis for this study was the recognition of the opportunity to enter the French market. Based on the interviews and written documents, we arrived at a detailed case history of each firm, in line with Pettigrew (1990), who suggests that organizing incoherent 
aspects in chronological order is an important step in understanding the causal links between events. Thereafter, on the basis of the interviews, we identified the unique patterns of each case and categorized the patterns observed under the subtopics derived from the three research questions we had set for the study. In addition, we used checklists and event listings to identify critical factors related to opportunity recognition (Miles and Huberman 1994). To ensure the accuracy of the coding of the categories, we used two senior researchers to validate the findings. We provided them with access to the case transcripts, and they independently classified the cases into categories manifesting the "activeness" and "alertness" of the case firms. The procedure was blind, since they did were unaware of the objectives of the study; we merely described to the researchers how we defined the terms "activeness" and "alertness." Their categorization was 100 percent consistent with our interpretations.

\section{Profiles of the Case Firms}

Firm A, which provides office equipment and manufactured products made of sheet metal, was established in 1876 . For almost the first 100 years, it was a domestic company. During its history, it has manufactured several products, many of which have been replaced by cheaper products produced in low-cost countries. Over the last 50 years, Firm A has bought several smaller companies, some successfully and others less so. It is now in its fifth generation, with its main growth and internationalization having taken place during the fourth generation. In 1970, Firm A started exporting to the Nordic countries. In 1980, exporting was expanded to Germany; and in 1982, export to France was launched. This led to the establishment of the subsidiary in France in 1984.

Firm B, which produces wooden toys, was established in 1923. Currently, the third generation is in charge of the business. The internationalization of Firm B began as early as 6 years from its establishment (for instance in 1929, when it exported to Sweden and England). In 1947, export to Argentina was launched, followed by new markets in 1960 (the United States, Denmark, Norway, and Iceland). The entry to France occurred in 1968, and the same distributor is still selling the firm's products in France. The product range of Firm B has been very similar throughout its history: traditional, educational wooden toys, which have hardly changed at all. Firm B still has exporting as its only mode of foreign operation, and it has only a small share of the market in all the countries exported to.

Firm C, founded in 1967, and currently run as a business by the second generation of the family, manufactures machines for forestry and agriculture. The internationalization of the firm began at the end of the1970s with exports to Sweden, Norway, and Denmark. Germany was entered in 1988 and Austria in 1995, both with distributors taking care of the exporting. France was entered in 1997 in the form of a subsidiary. Nonetheless, another product of Firm C was taken to France 1 year later via a distributor.

In the case of Firm D, which manufactures $\log$ houses, internationalization started 21 years after its establishment (1973), and continued in 1994 with the export of log houses to Germany and Japan. The French trade started in 1998 in the form of exporting. It was intended that a network of distributors would be formed, but the attempts to find reliable people failed. Hence, a representative office was established in France in 2002 with a view to facilitating administration.

The story of Firm E, currently run by the second generation, began in 1972 . This firm manufactures different kinds of packaging materials. Poland was its first export market (1985). The firm exported 
to 10 European countries and had a subsidiary in Poland before it entered France in 1989. The operational mode in the French market changed to a joint venture involving a production plant in 2006. During the time of the second generation of the business (which is 100 percent owned by the son of the founder), the internationalization of the firm has been very intense. It now has subsidiaries in 14 countries and sales in over 60 countries worldwide.

Firm $F$ was launched in 1988 by an experienced entrepreneur. This firm produces various products including pipettes and analyzing systems. It has always been very intense in its innovations and patenting policy. It is one of the leading companies in its field in the world. The first foreign market, entered in 1991 in the form of a production subsidiary, was France. For this entrepreneur, internationalization was fairly easy, being based on strong international industrial relationships.

Firm G, which was founded in 1978, produces fire safety equipment. This industry is highly traditional and also extremely diversified, since different countries have different kinds of fire safety equipment. In the 1980s, Firm G started exporting to Norway, Sweden, Germany, and Estonia. Exports to France were launched in 1991. This was preceded by imports from France, starting in 1990.

Firm $H$ is a producer of sauna stoves and sauna equipment in general. The firm is now in its third generation as a family business, having been founded in 1955. At the beginning of the 1990s, Firm $\mathrm{H}$ started exporting to several markets-10 European countries altogether, including the Nordic countries and Germany-before it launched exports in the French market.

\section{Findings}

This section will present how the opportunity to enter France was recog- nized in the case firms. On the basis of previous literature and the interview data, this section will divide the findings into three categories of factors affecting the firms' international opportunity recognition, as detailed below.

First of all, international opportunity recognition will be considered from the perspective of network ties, with a division into formal ties (with other firms) informal ties (with friends) (Coviello and Munro 1997; Ojala 2009), and family ties (with family members) (Ozgen and Baron 2007). Second, the level of active ness and alertness of the firms in their international opportunity recognition will be assessed as high, medium, or low. The level of activeness is high if a firm proactively planned to enter the French market. If a firm actively sought out new contacts for internationalization but had not actively considered opportunities in France, the firm can be considered as having medium-level activeness. A low level of activeness means that a firm did not do anything to enter new markets. In the case of alertness, a firm's alertness was high if it immediately reacted to an opportunity to enter the French market. Medium-level alertness means that a firm did not immediately react to new perceptions, but after consideration or a decision process, it seized the opportunity to enter the French market. If a firm did not react to an opportunity to enter France, its alertness can be regarded as low. Third, the prior knowledge of the case firms will be discussed in relation to the industry concerned, the firm's internationalization, and its market-specific knowledge of the French market (Johanson and Vahlne 1977; Ozgen and Baron 2007; Shane 2000). At the end of the section, the primary context in which the opportunity to enter a foreign market was recognized will be discussed.

Due to space limitations, the findings will be presented by grouping together the firms that had similar elements in their opportunity recognition rather than 
by describing each individual case firm separately. The findings are summarized in Table 2. It should be noted that the classification is bound to be subjective to a certain extent, given the qualitative method applied.

\section{Network Ties Used by the \\ Case Firms}

As Table 2 illustrates, the network ties involved in international opportunity recognition were formal ties with other firms and informal ties with friends. It is interesting that family ties with family members were not relevant to opportunity recognition in these case firms. Formal ties were the most important ties in the opportunity recognition of all the case firms, with the exception of Firm F. In the case of Firm $\mathrm{F}$, the entrepreneur had previous experience of the French market based on his previous firm. This entrepreneur was able to utilize networks formed during the firm he had been with before. Thus, he was able to recognize the opportunity to enter France through a good friend who had been a previous business partner there. The entrepreneur and the French friend had simultaneously suggested that a French production subsidiary should be established to carry on their previous business. Hence, in Firm F, the most important tie in the opportunity recognition was an informal one.

In all the other case firms, formal ties played a central role in the opportunity recognition. It is worth noting that in four of the seven cases these formal ties were formed at international trade exhibitions. These firms (A, B, E, and $\mathrm{H}$ ) had participated in trade exhibitions to look for suitable business partners, but none of them were concentrating on a search for French partners solely. Eventually, the opportunity to enter the French market became an obvious route for these firms, when they formed some potential French ties with people who showed interest in their products at the trade exhibitions. The representative of Firm B described it in the following way:

Trade exhibitions are extremely important for us, that is where all our contacts are made. And that is where we also met our future French agent. We already had business in some countries in Central Europe, and had in mind that France might have potential as well. And we have found dozens of new French candidates ever since in those trade exhibitions. Last year it was our 41 st time there...

In Firms D and G, the way they encountered the formal tie was somewhat unstructured. The representative of Firm D met the future business partner by coincidence, when a French entrepreneur living in Finland met the representative in one of its log houses (this being the product that Firm D exported to France). The entrepreneur was keen on starting to export the log houses to France because he saw France as having a great deal of potential for this kind of product. In Firm $G$, the opportunity to enter France was perceived thanks to a French supplier from whom Firm G imported. At one point, the business partner in France asked if the firm would consider exporting some pieces to France, and this was in fact the main context for the opportunity recognition: an existing, formal tie in the French market. Firm C, by contrast, had a more structured way of perceiving the opportunity to operate in France. It made use of a formal tie, hiring a consultant who had lived in France for a long period to conduct market research. It was only in Firms $\mathrm{G}$ and $\mathrm{F}$ that the recognition of the opportunity for market entry was facilitated by network ties that already existed. In the other case firms, new ties were established and these facilitated their opportunity recognition. 
JOBNAME: No Job Name PAGE: 13 SESS: 21 OUTPUT: Fri Apr 8 18:27:35 2011 SUM: 7F37BF73 /v2503/blackwell/journals/jsbm_v49_i3/jsbm_326

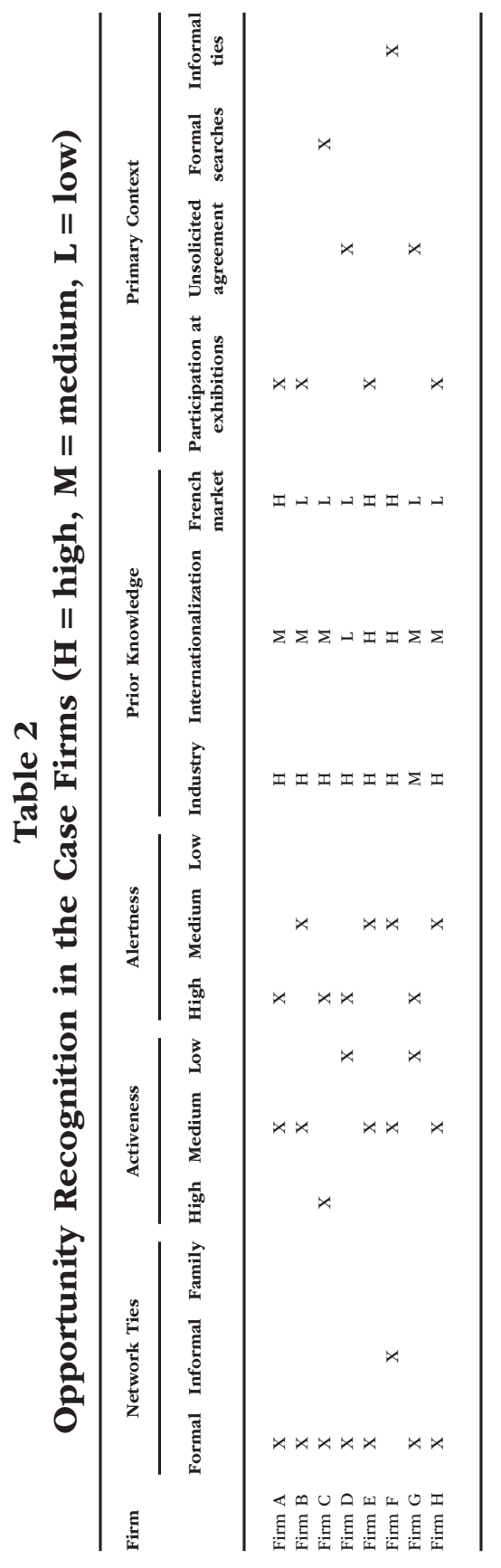

KONTINEN AND OJALA 


\section{Activeness and Alertness of the Case Firms in the Search for Opportunities}

The activeness and alertness shown in the international opportunity recognition has been classified as high, medium, or low based on the interview data (see Table 3 for more detailed information on each firm's activeness and alertness). Only Firm $\mathrm{C}$ is classified as "high" in its activeness. Firm C conducted market research, since it proactively planned to enter the French market. However, it wanted initially to explore whether the French market truly had potential for its product. In Firms A, B, E, F, and $\mathrm{H}$, the level of activeness is considered "medium." Firms $\mathrm{A}, \mathrm{B}, \mathrm{E}$, and $\mathrm{H}$ actively participated in trade exhibitions involving their industry. However, they did not actively search for French opportunities by any other means, and when they attended the exhibitions, they sought out new contacts irrespective of the country the contacts might have originated from. In Firm $F$, the level of activeness is also regarded as medium, since the entrepreneur did not need to be active in persuading his French friend and previous business partner to launch a subsidiary in France. The entrepreneur in Firm $F$ described the decision to enter the French market as follows:

Well, it happened by itself, because we were such good friends. I don't even know who asked first, me or him. Maybe he was the one. It was so natural that he would set up the subsidiary when I set up my enterprise in Finland.

In Firms D and G, the level of activeness is regarded as low, since the staff in these firms did not do anything themselves with a view to entering new markets. They entered the French market because their products were ordered, without any action on their side. However, regarding the level of alertness, it was high in these inactive Firms $D$ and $G$, since they immediately grabbed the opportunity to enter the French market despite having no existing plans to enter that market. In Firms $\mathrm{A}$ and $\mathrm{C}$, too, the level of alertness can be regarded as high, since they immediately reacted to possibilities offered by external parties. For instance, in Firm $\mathrm{C}$, the entrepreneur quickly reacted to the offer made by Finpro (Finnish export promotion organization) that a Finnish woman who had been their employee, but who was unemployed at that point, could immediately begin the process of establishing a subsidiary in France.

In the remaining firms, $\mathrm{B}, \mathrm{E}, \mathrm{F}$, and $\mathrm{H}$, the level of alertness is considered medium. These firms did not immediately react to new perceptions but finally seized the opportunity to enter France without any lengthy debates or decision processes. The entrepreneur of Firm $\mathrm{H}$ had made some interesting contacts at international trade exhibitions, but it was only when these French persons contacted Firm $\mathrm{H}$ and insisted on selling their products in France that they grabbed the opportunity. Hence, they were inactive in developing the ties they made at trade exhibitions.

Most of the entrepreneurs (in Firms B, $\mathrm{D}, \mathrm{E}, \mathrm{G}$, and $\mathrm{H}$ ) recognized that the flexibility and small management teams of family firms enabled them to be alert and reactive to international opportunities. The owner-manager of Firm D put it this way:

We had no plan to go to France. My colleague just met this French guy by coincidence. He said that he wanted to sell our loghouses in France. [. . .] Well, then I went to see him and said okay, just go ahead and start selling our loghouses. [...] Making quick deci- 
JOBNAME: No Job Name PAGE: 15 SESS: 21 OUTPUT: Fri Apr 8 18:27:35 2011 SUM: 5C749BF0 /v2503/blackwell/journals/jsbm_v49_i3/jsbm_326

Table 3

Activeness and Alertness in the Case Firms: Personalized Examples

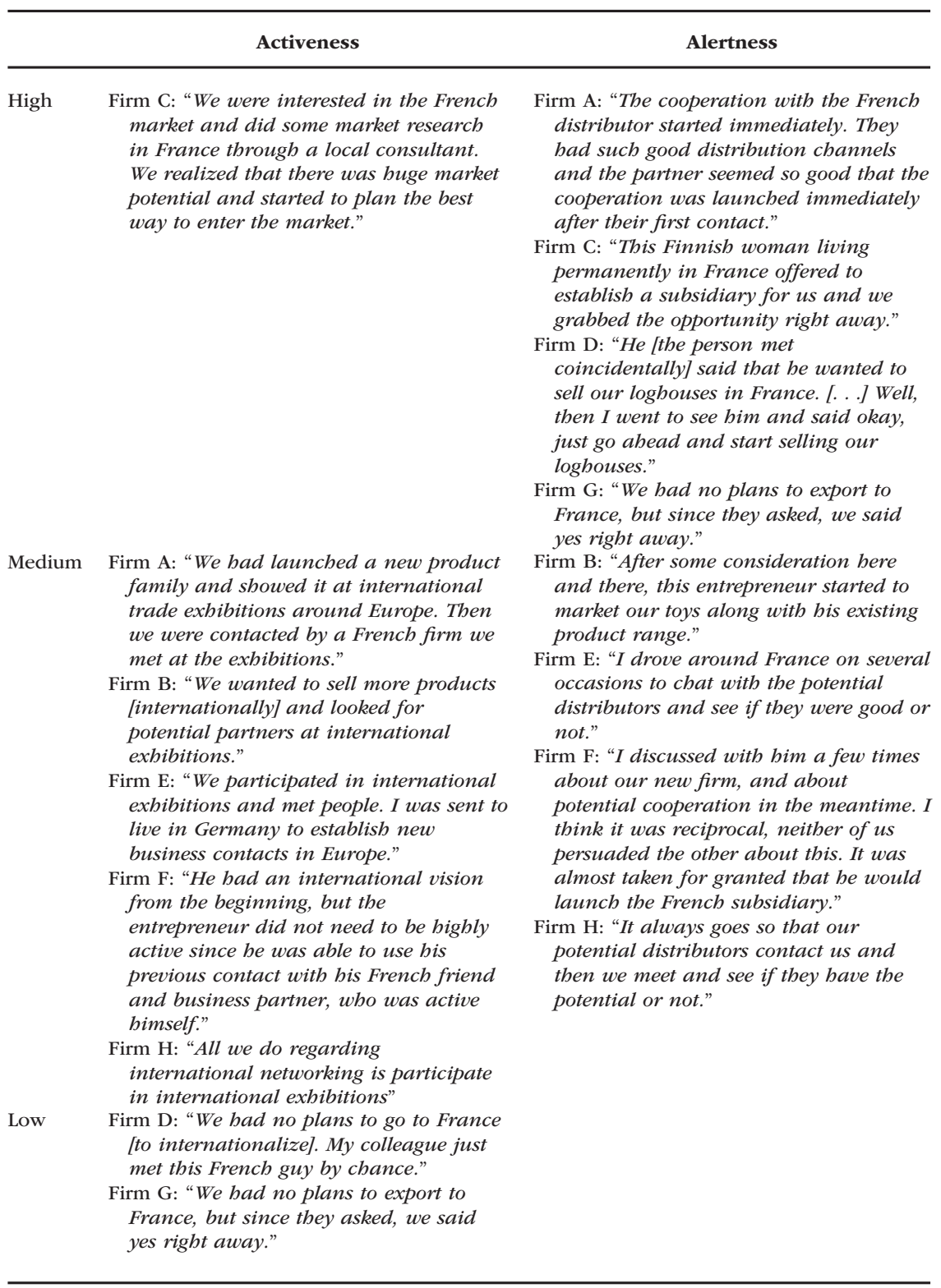


sions is possible in a small familyowned company. It's our big advantage.

This flexibility is also evident among the firms ranked as medium level in their alertness, although their reaction to international opportunities was not so quick at the time of market entry to France. For instance, the owner-manager of Firm E commented on this as follows:

We have no obstacles to executing and doing things, because, well, our organization works flexibly and innovatively. It is one of the biggest advantages of familyowned companies.

Prior Knowledge of the Case Firms

The prior knowledge of the entrepreneurs in the case firms can be divided into industry-specific knowledge, internationalization knowledge, and marketspecific knowledge. The industry-specific knowledge in all the case firms-except for Firm G-was high. Their knowledge was mainly based on experience, in other words, on a long product development process. These firms that had high industry knowledge had an excellent, in some ways, original product, which had basically good competitiveness in international markets. They also knew fairly well what their rivals were doing. Thus, Firm A launched a new product family just before entering France, and those successful innovative products were later imitated by their rivals. The industryspecific knowledge of Firm $G$ is regarded as medium, since they were not very familiar with the products offered by other European firms; hence, they did not entirely know what their firm could offer abroad, and had not planned to internationalize.

The internationalization knowledge was of medium level in most of the case firms (A, B, C, G, and H). The level of internationalization knowledge can be regarded as medium if the entrepreneur has experiential knowledge, in other words, experience gained from foreign operations. For instance, the entrepreneur of Firm $\mathrm{H}$ had operated in several foreign markets before entry to the French market. However, the internationalization process of the firm was reactive to requests from abroad, which meant that its staff did not need to be very deeply involved in knowing about internationalization as such. In Firm D, the internationalization knowledge is regarded as low, since the entrepreneur of Firm D had only a very small degree of international experience, based on occasional visits to Germany and Japan. By contrast, the internationalization knowledge of firms $\mathrm{E}$ and $\mathrm{F}$ can be regarded as high at the time of recognition of the opportunity to enter the French market. Firm E already had production subsidiaries around the world and had been selling to numerous countries for several years. Despite this, their attitude to internationalization was extremely innovative and proactive. The entrepreneur in Firm $F$ had a foundation of internationalization experience since his previous firms had been selling and producing goods all around the world for more than 10 years before this specific opportunity was recognized.

Five out of eight case firms (B, C, D, $G$, and $H$ ) had surprisingly limited knowledge of the French market before they recognized the opportunity to enter the market. None of these firms had experiential knowledge of France nor did they set out to gather any explicit knowledge, even before they entered the French market. For instance, in Firm D the entrepreneur described the knowledge of France in this way:

Well, it [the entry to France] has been quite unorganized. We have made many mistakes and learned from them. I had no cultural knowledge of France and I 


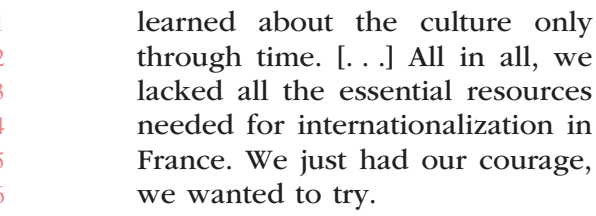

9 In Firms $\mathrm{A}, \mathrm{E}$, and $\mathrm{F}$, by contrast, the level of French market knowledge is perceived as high, the reason for this being is the experiential knowledge gained by the entrepreneurs or their family members. In Firm A, the entrepreneur had lived in France for several years; he had experiential knowledge of French culture and also knew the French language. In Firm E, too, there was a family member who knew French language and culture, since he was living on the French border at the time of the opportunity recognition. In Firm $F$, French market knowledge was at a very high level. This was due to the fact that the entrepreneur had cooperated for several years with the French because of the business operations of his preceding firms, which were operating in the same field.

\section{The Primary Context of the International Opportunity Recognition}

In this section, we shall summarize the main findings uncovered via an analysis of the network ties, activeness and alertness, and prior knowledge of the case firms. In so doing, we shall discuss the phenomenon of international opportunity recognition from the point of view of its primary context. The primary contexts, as found in the data, were trade exhibitions, unsolicited agreements, formal searches, and informal ties. As Table 2 illustrates, the

10 primary context of international opportunity recognition was in half of the cases (A, B, E, and $\mathrm{H}$ ) their participation in trade exhibitions. In fact, this venue appears to form the most important context for opportunity recognition.
The second most common context for recognizing the opportunity to enter the French market was an unsolicited agreement-a phenomenon that occurred for Firms D and G. Firm D needed to find new markets but had no strategy on how to internationalize. Hence, Firm D did not actively look for anyone to sell their products abroad, did not ask any person to sell its products, and did not invest any money on this attempt. In fact, it was an entrepreneur who was himself of French origin who invested his own money in bringing Firm D to the French market. Firm G, by contrast, took the opportunity to export to France when its French supplier asked if Firm G could provide the supplier with a certain component that it not produce itself. In fact, there was a year of importing on the background before this French supplier asked Firm G to start selling products to France, via the supplier.

For Firm $\mathrm{C}$, the primary context of opportunity recognition consisted entirely of a formal search. As it showed that France had great potential, Firm C immediately started to plan its foreign market entry in a strategic fashion. The discovery of suitable entrepreneurs to carry out its French plan was also essential in the execution of the French opportunity. Nevertheless, the two entrepreneurs concerned were not involved in the primary opportunity recognition phase, since the decision on entry had been made on the basis of the market search.

Firm F differed notably from the other firms in its opportunity recognition, since the entrepreneur-founder of Firm $F$ had a good, trustworthy friend in France, with whom he had been doing business for 10 years (while with his previous firms). Hence, when this entrepreneur set up Firm F, it seemed obvious to him that he could start a subsidiary in France, given that he knew a trustworthy, excellent person there who was acquainted with this particular industry. Nothing 
else was needed in discovering the opportunity to operate in France. Thus, the presence of the informal tie had a great effect on the manner of opportunity recognition. However, with all the other firms, it was mainly formal ties that were involved in the opportunity recognition. And taking the firms altogether, the manner of recognizing the opportunity was, to a large extent, based on the finding of suitable persons (by coincidence or at a trade exhibition) to represent the firm's products in France.

\section{Discussion}

The findings indicate that formal ties can be regarded as essential in the international opportunity recognition of family SMEs. Only one firm recognized the opportunity via informal ties. However, none of the firms was able to utilize family ties in the international opportunity recognition process. This finding supports the study of Ozgen and Baron (2007), which suggests that family ties do not facilitate the opportunity recognition process. In other words, the close relationships that commonly exist between family members or the informal relationships existing between friends reduce opportunities for getting new and valuable information that could promote international opportunity recognition. However, in formal relationships, the potential for recognizing international opportunities is much higher (compare Burt 2004; Granovetter 1973).

One interesting finding is that only two of the case firms recognized the opportunity for the foreign market entry through an existing network tie (through a formal tie with the supplier and through an informal tie with a friend in France). In the other six cases, the international opportunity recognition actually led to the formation of new formal ties in trade exhibitions, or else it came as a response to unsolicited inquiries. This finding suggests that in family SMEswhere there are not many international connections (Graves and Thomas 2004)_existing network ties do not generally lead to international opportunity recognition. Our study takes the findings of Graves and Thomas (2004) further, since it suggests that in the context of international opportunity recognition, family SMEs generally compensate for their limited network ties by forming new, formal network ties. However, it should be noted that this finding is inconsistent with the studies of Ellis (2008) and Singh (2000) (on nonfamily firms), which indicated the importance of existing network ties in opportunity recognition; in our study, family SMEs used new network ties rather than existing ones. On the basis of our findings, we can arrive at the following two propositions:

Proposition 1: Family SMEs recognize international opportunities by using formal ties rather than informal ties or family ties.

Proposition 2: Among family SMEs, the formation of new network ties is more likely to lead to international opportunity recognition than the presence of existing ties.

We observed that a high level of activeness led to opportunity recognition through a formal search, whereas a low level of activeness led to opportunity recognition via an unsolicited inquiry. The case firms with a medium level of activeness realized the international opportunity via trade exhibitions or informal ties. The concept of alertness describes the actions taken by family SMEs very well: all of them reacted fairly proactively to opportunities, irrespective of the level of activeness. This might be, generally speaking, connected to the unsystematic way of internationalizing in family firms (Tsang 2001); only one case firm had a plan to internationalize in France at the time of opportunity recognition. 
It also seems that small management teams provide a distinct advantage in relation to the alertness of family SMEs: they allow decision processes to be quick and flexible (compare Gallo and Pont 1996; Tsang 2001). Hence, they can proactively seize emerging opportunities, whether they are actively looking for new international opportunities or not. On that basis, we would posit the following:

\section{Proposition 3: Among family SMEs, international opportunities are likely to be recognized on the basis of alertness rather than activeness. \\ Proposition 4: The flexibility of the governance structure in family SMEs is positively related to a high level of alertness in international opportunity recognition.}

It is interesting that prior knowledge (including industry-specific knowledge, internationalization knowledge, and market-specific knowledge) had no significant effect on international opportunity recognition. This was despite the fact that several studies have underlined the importance of prior knowledge for both opportunity recognition in general (Baron 2006; Shane 2000) and international opportunity recognition in particular (Johanson and Vahlne 1977; Oviatt and McDougall 1995; Reuber and Fischer 1997). Thus, although the prior industry knowledge of the family SME entrepreneurs seemed to be strong, it did not seem to facilitate their international opportunity recognition to any great extent since most of the firms had no international industry relations. In addition, their market-specific knowledge was limited in most cases, and within those firms that did possess high knowledge of French culture and language, this knowledge did not significantly contribute to the opportunity recognition process since they had not developed relations in the French market that would serve business purposes. Altogether, in the international opportunity recognition phase, prior knowledge plays a fairly minor role (although its importance may increase when a firm starts to execute the perceived opportunity). This might be connected to family entrepreneurs' desire to avoid risks and to protect the socio-emotional wealth of their staff (Gomez-Mejia, Makri, and Kintana 2010), with the implication that their opportunity recognition is based on finding trustworthy partners. In other words, whether or not they have experience of internationalization or knowledge of the target market from a nonbusiness context, they recognize their opportunity only when they meet a potential cooperator, often in international trade exhibitions or by coincidence. By meeting cooperators personally, also the risk connected to foreign market entry is reduced.

The findings of this study indicate that the primary context in which the family SMEs recognize the opportunity for foreign market entry is that of trade exhibitions. $^{2}$ This is consistent with earlier literature indicating the important role of trade exhibitions for opportunity recognition (Ellis 2000; McAuley 1999; Meyer and Skak 2002). Trade exhibitions form a context with a dense network that facilitates access to important information since persons in the network can easily share essential knowledge (compare Burt 2000). Consequently, trade exhibi-

${ }^{2}$ In two cases, unsolicited inquiries were the primary context of the opportunity recognition. This again underlines the importance of alertness to opportunities (Ardichvili, Cardozo, and Ray 2003; Kirzner 1997) and the role of serendipity in foreign market entry (Crick and Spence 2005; McAuley 1999; Meyer and Skak 2002). 
tions and similar forums where people share common interests are a context in which potential business partners may well be found, without the investment of huge amounts of money or time. They form a natural context for family SMEs, which often have limited financial resources and which tend to have a cautious attitude regarding investments and changes in operations (for example Gallo and Pont 1996; Graves and Thomas 2008). This finding is also in line with the observation of Ellis (2008) that firms compensate for their limited networks by participating in trade exhibitions. In addition, international exhibitions may be important for the reason that family business owners do not want to use external sources to facilitate their internationalization (Graves and Thomas 2004). All in all, in relation to Proposition 2 , it can be stated that although family SMEs utilized new network ties in their international opportunity recognition, these were generally found in forums with a high network density. In these forums, the amount of potential network ties is high (Coviello 2006) and the interaction between different parties is facilitated (Oviatt and McDougall 2005). From all these considerations, we derive the final proposition, as follows:

Proposition 5: Forums with a high network density are the primary context in which family SMEs recognize opportunities for foreign market entry.

\section{Conclusions}

This study makes several contributions in the fields of international business and international entrepreneurship. First, it answers the calls for more research on international opportunity mentioned in the Introduction (Dimitratos and Jones 2005; Ellis 2008; Young, Dimitratos, and Dana 2003; Zahra, Korri, and $\mathrm{Yu}$ 2005). Second, it indicates how network ties, activeness and alertness, and prior knowledge affect internationa opportunity recognition. Third, the study identifies the primary context in which family SMEs recognize international opportunities for new market entry. Our findings suggest that SMEs mainly recognize international opportunities by establishing new formal ties, with existing informal ties and family ties having a less significant role. We also found that international opportunity recognition of family SMEs is more related to alertness to new international opportunities than to an active search for opportunities. This seems to be due to the small size and flexibility of the management teams concerned. Furthermore, the findings indicated that prior knowledge did not directly affect the international opportunity recognition of family SMEs. Finally, forums with a high network density were the primary context for international opportunity recognition.

International opportunity recognition is an emerging research topic in international entrepreneurship. Although our study provides an empirical contribution to this topic, there is a plenty of scope for further research. The study offers five propositions for further quantitative testing-necessary, since the findings of this study are not widely generalized due to the methodological circumstances. Our research setting also limits the case firms to family-owned SMEs. Although this approach has the advantage of a specific focus, one would clearly wish to take the research into broader contexts. Thus, further studies are needed in relation to the international opportunity identification of early internationalizing firms and firms that have different kinds of ownership structures. In this study, the focus was solely on opportunities that were actually implemented. Hence, there is also a need for further research on international opportunities that were recognized but not implemented, and the mechanisms that might lie behind the implementation of some international 


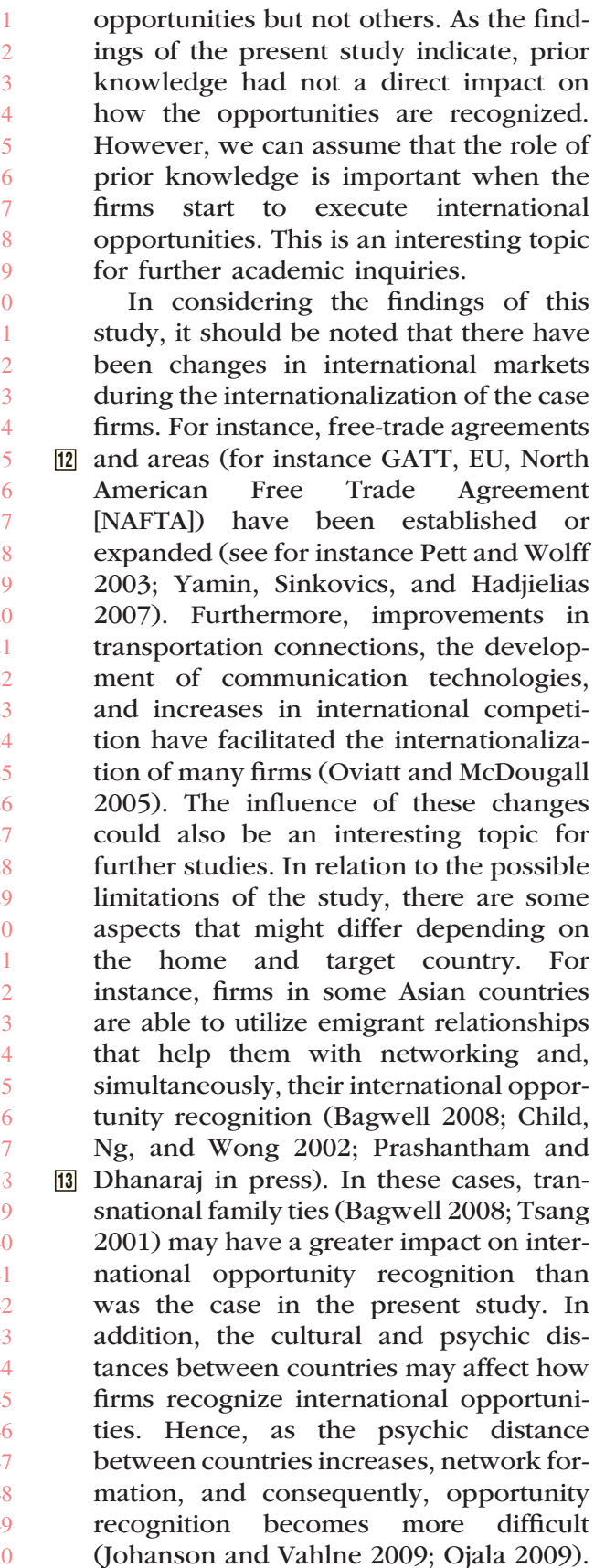

From a managerial point of view, family entrepreneurs with limited networks should concentrate on actively looking for new formal ties, which can provide them with novel information on international opportunities. Due to the closeness of family ties, the families themselves generally do not offer this kind of information. International trade exhibitions are an excellent context for family SMEs to engage in networking. Family SMEs with flexible management teams should also take advantage of their ability to be alert, in other words, their ability to quickly react to opportunities that arise in different contexts, often by mere coincidence.

\section{References}

Aldrich, H. (1999). Organizations Evolving. London: Sage.

Ardichvili, A., R. Cardozo, and S. Ray (2003). "A Theory of Entrepreneurial Opportunity Identification and Development," Journal of Business Venturing 18(1), 105-123.

Arregle, J.-L., M. Hitt, D. Sirmon, and P. Very (2007). "The Development of Organizational Social Capital: Attributes of Family Firms," Journal of Management Studies 44(1), 73-95.

Bagwell, S. (2008). "Transnational Family Networks and Ethnic Minority Business Development: The Case of Vietnamese Nail-Shops in the UK," International Journal of Entrepreneurial Behaviour and Research 14(6), 377-394.

Baron, R. A. (2006). "Opportunity Recognition as Pattern Recognition: How Entrepreneurs 'Connect the Dots' to Identify New Business Opportunities," Academy of Management Perspectives 20(1), 104-119.

Bonoma, T. V. (1985). "Case Research in Marketing: Opportunities, Problems, and a Process," Journal of Marketing Research 22(2), 199-208.

Brown, S. L., and K. M. Eisenhard (1997). "The Art of Continuous Change: 
Linking Complexity Theory and TimePaced Evolution in Relentlessly Shifting Organizations," Administrative Science Quarterly 42, 1-34.

Burt, R. S. (2000). "The Network Structure of Social Capital," Research in Organizational Behaviour 22, 345423.

(2004). "Structural Holes and Good Ideas," American Journal of Sociology 110(2), 349-399.

Child, J., S. H. Ng, and C. Wong (2002) "Psychic Distance and Internationalization: Evidence from Hong Kong Firms," International Studies of Management and Organization 32(1), 36-56.

Chrisman, J. J., J. H. Chua, and L. Steier (2005). "Sources and Consequences of Distinctive Familiness: An Introduction," Entrepreneurship Theory and Practice 29, 237-247.

Claver, E., L. Rienda, and D. Quer (2008). "Family Firms' Risk Perception: Empirical Evidence on the Internationalization Process," Journal of Small Business and Enterprise Development 15(3), 457-471.

Coviello, N. (2006). "The Network Dynamics of International New Venture," Journal of International Business Studies 37(5), 713-731.

Coviello, N., and H. Munro (1997). "Network Relationships and the Internationalisation Process of Small Software Firms," International Business Review 6(4), 361-386.

Coviello, N. E., and M. V. Jones (2004). "Methodological Issues in International Entrepreneurship Research," Journal of Business Venturing 19(4), 485-508.

Creswell, J. W. (1997). Qualitative Inquiry and Research Design: Choosing Among Five Traditions. Newbury Park, CA: Sage Publications.

Crick, D., and M. Spence (2005). "The Internationalisation of 'High Performing' UK High-Tech SMEs: A Study of Planned and Unplanned Strategies,"
International Business Review 14(2), 167-185.

Dimitratos, P., and M. Jones (2005). "Future Directions for International Entrepreneurship Research," International Business Review 14(2), 119128.

Donckels, R., and E. Fröhlich (1991). "Are Family Businesses Really Different? European Experiences from STRATOS," Family Business Review 12(2), 146-160.

Eisenhardt, K. M. (1989). "Building Theories from Case Study Research," Academy of Management Review 14(4), 532-550.

Ellis, P. (2000). "Social Ties and Foreign Market Entry," Journal of International Business Studies 31(3), 443-469.

- (2008). Social Ties and International Opportunity Recognition. Unpublished manuscript, Hong Kong Polytechnic University.

Fernandez, Z., and M. J. Nieto (2005) "Internationalization Strategy of Small and Medium-Sized Family Businesses: Some Influential Factors," Family Business Review 18(1), 77-89.

Finpro (2008). Subsidiaries of Finnish Companies in France-July 2008. Paris: Finpro.

Gallo, M. A., and C. G. Pont (1996). "Important Factors in Family Business Internationalization," Family Business Review 9(1), 45-59.

Gomez-Mejia, L. R., M. Makri, and M. L. Kintana (2010). "Diversification Decisions in Family-Controlled Firms," Journal of Management Studies 47(2), 223-252.

Granovetter, M. S. (1973). "The Strength of Weak Ties," American Journal of Sociology 76(6), 1360-1380.

Graves, C., and J. Thomas (2004). "Internationalisation of the Family Business: A Longitudinal Perspective," International Journal of Globalisation and Small Business 1(1), 7-27.

- (2006). "Internationalization of Australian Family Businesses: A Mana- 
gerial Capabilities Perspective," Family Business Review 19(3), 207224.

(2008). "Determinants of the Internationalization Pathways of Family Firms: An Examination of Family Influence," Family Business Review 21(2), 151-167.

Hills, G. E., and R. C. Schrader (1998). "Successful Entrepreneur's Insights into Opportunity Recognition," in Frontiers of Entrepreneurship Research. Eds. P. D. Reynolds et al. Wellsley, MA: Babson College, 30$14 \quad 43$.

Hohenthal, J., J. Johanson, and M. Johanson (2003). "Market Discovery and the International Expansion of the Firm," International Business Review 12(6), 659-672.

Huber, G. P., and D. J. Power (1985). "Retrospective Reports of StrategicLevel Managers: Guidelines for Increasing Their Accuracy," Strategic Management Journal 6, 171-180.

Johanson, J., and L.-G. Mattsson (1992). "Network Positions and Strategic Action: An Analytical Framework," in Industrial Networks: A New View of Reality. Eds. B. Axelsson and G. Easton. New York: Routledge, 205217.

Johanson, J., and J.-E. Vahlne (1977). "The Internationalization Process of the Firm-A Model of Knowledge Development and Increasing Foreign Market Commitments," Journal of International Business Studies 8(1), 23-32.

- (2009). "The Uppsala Internationalization Process Model Revisited: From Liability of Foreignness to Liability of Outsidership," Journal of International Business Studies 40, 1411-1431.

Khilström, R., and J. Laffont (1979). "A General Equilibrium Entrepreneurial Theory of Firm Formation Based on Risk Aversion," Journal of Political Economics 87(4), 719-748.
Kirzner, I. M. (1979). Perception, Opportunity, and Profit: Studies in the Theory of Entrepreneurship. Chicago, IL: University of Chicago Press.

(1997). "Entrepreneurial Discovery and the Competitive Market Process: An Austrian Approach," Journal of Economic Literature 35(1), 60-85.

Kontinen, T., and A. Ojala (2010). "The Internationalization of Family Businesses: A Review of Extant Research," Journal of Family Business Strategy 1(2), 97-107.

Krueger, N. F., and D. V. Brazeal (1994). "Entrepreneurial Potential and Potential Entrepreneurs," Entrepreneurship Theory and Practice 18(3), 91-104.

McAuley, A. (1999). "Entrepreneurial Instant Exporters in the Scottish Arts and Crafts Sector," Journal of International Marketing 7(4), 67-82.

McDougall, P. P., S. Shane, and B. M. Oviatt (1994). "Explaining the Formation of International New Ventures: The Limits of Theories from International Business Research," Journal of Business Venturing 9(6), 469-487.

Meyer, K., and A. Skak (2002). "Networks, Serendipity and SME Entry into Eastern Europe," European Management Journal 20(2), 179-188.

Miles, M. B., and A. M. Huberman (1994). Qualitative Data Analysis: An Expanded Sourcebook. Newbury Park, CA: Sage Publications.

Miller, C. C., L. B. Cardinal, and W. H. Glick (1997). "Retrospective Reports in Organizational Research: A Reexamination of Recent Evidence," Academy of Management Journal 40(1), 189-204.

Organization for Economic Co-operation and Development (2003). OfficiallySupported Export Credits and Small Exporters. - , France: Organization for Economic Co-operation and Development.

Ojala, A. (2008). "Entry in a Psychically Distant Market: Finnish Small and 
Medium-Sized Software Firms in Japan," European Management Journal 26(2), 135-144.

(2009). "Internationalization of Knowledge-Intensive SMEs: The Role of Network Relationships in the Entry to a Psychically Distant Market," International Business Review 18(1), $50-59$.

Okoroafo, S. C. (1999). "Internationalization of Family Businesses: Evidence from Northwest Ohio, U.S.A.," Family Business Review 12(2), 147-158.

Oviatt, B. M., and P. P. McDougal (1995). "Global Start-Ups: Entrepreneurs on a Worldwide Stage," Academy of Management Executive 9(2), 30-43.

(2005). "Defining International Entrepreneurship and Modeling the Speed of Internationalization," Entrepreneurship Theory and Practice 29(5), 537-553.

Ozgen, E., and R. A. Baron (2007) "Social Sources of Information in Opportunity Recognition: Effects of Mentors, Industry Networks, and Professional Forums," Journal of Business Venturing 22(2), 174-192.

Park, J. S. (2005). "Opportunity Recognition and Product Innovation in Entrepreneurial Hi-Tech Start-Ups: A New Perspective and Supporting Case Study," Technovation 25(7), 739752.

Pett, T. L., and J. A. Wolff (2003). "Firm Characteristics and Managerial Perceptions of NAFTA: An Assessment of Export Implications for U.S. SMEs," Journal of Small Business Management 41(2), 117-132.

Pettigrew, A. M. (1990). "Longitudinal Field Research on Change: Theory and Practice," Organization Science 1(3), 267-292.

Prashantham, S., and C. Dhanaraj (in press). "The Dynamic Influence of Social Capital on the International Growth of New Ventures," Journal of

[16] Management Studies $\bullet \bullet, \cdot \bullet . \bullet$.
Reid, S. D. (1984). "Information Acquisition and Export Entry Decisions in Small Firms," Journal of Business Research 12(2), 141-157.

Reuber, A. R., and E. Fischer (1997). "The Influence of the Management Team's International Experience on the Internationalization Behavior of SMEs," Journal of International Business Studies 28(4), 807-825.

Salvato, C., and L. Melin (2008). "Creating Value Across Generations in Family-Controlled Businesses: The Role of Family Social Capital," Family Business Review 21(3), 259-276.

Sarasvathy, D., H. Simon, and L. Lave (1998). "Perceiving and Managing Business Risks: Differences between Entrepreneurs and Bankers," Journal of Economic Behavior and Organization 33, 207-225.

Shane, S. (2000). "Prior Knowledge and the Discovery of Entrepreneurial Opportunities," Organization Science 11(4), 448-469.

Shane, S., and S. Venkataraman (2000). "The Promise of Entrepreneurship as a Field of Research," Academy of Management Review 26(1), 13-17.

Shrader, R. C., B. M. Oviatt, and P. P. McDougall (2000). "How New Ventures Exploit Trade-Offs among International Risk Factors: Lessons for the Accelerated Internationalization of the 21st Century," Academy of Management Journal 43(6), 12271247

Singh, R. P. (2000). Entrepreneurial Opportunity Recognition through Social Networks. New York: Garland Publishing.

Tsang, E. W. K. (2001). "Internationalizing the Family Firm: A Case Study of a Chinese Family Business," Journal of Small Business Management 39(1), 88-94.

Venkataraman, S. (1997). "The Distinctive Domain of Entrepreneurship Research," in Advances in Entrepreneurship, Firm Emergence and 
JOBNAME: No Job Name PAGE: 25 SESS: 21 OUTPUT: Fri Apr 8 18:27:35 2011 SUM: 5091714A /v2503/blackwell/journals/jsbm_v49_i3/jsbm_326

Growth. Eds. J. Katz and R. Brockaus. Greenwich, CT: JAI Press, 119-138.

Yamin, M., R. Sinkovics, and E. Hadjielias (2007). "EU Harmonization, Managerial Perceptions and SME Export Behavior," Journal of Euromarketing 17(1), 7-21.

Yin, R. K. (1994). Case Study Research Design and Methods, 2nd ed. Newbury Park, CA: SAGE Publications.

Young, S., P. Dimitratos, and L.-P. Dana (2003). "International Entrepreneurship Research: What Scope for International Business Theories?" Journal of International Entrepreneurship 1(1), 31-42.

Zahra, S. A. (2003). "International Expansion of U.S. Manufacturing Family Businesses: The Effect of Ownership and Involvement," Journal of Business Venturing 18(4), 495-512.

Zahra, S. A., J. S. Korri, and J. F. Yu (2005). "Cognition and International Entrepreneurship: Implications for Research on International Opportunity Recognition and Exploitation," International Business Review 14(2), 129-146. 